\title{
Eingesandte Literatur
}

Berg, Thomas: Die Abbildung des Sprachproduktionsprozesses in einem Aktivationsflußmodell. Untersuchungen an deutschen und englischen Versprechern. - Tübingen: Max Niemeyer 1988. 222 S. (= Linguistische Arbeiten. 206).

Clahsen, Harald: Normale und gestörte Kindersprache. Linguistische Untersuchungen zum Erwerb von Syntax und Morphologie. - Amsterdam \& Philadelphia: John Benjamins Publishing Company 1988.

Exlorations in dependency phonology. 〈Eds. $\rangle$ : John Anderson and Jacques Durand. Dordrecht \& Providence, RI: Foris Publications 1987. 220 S. (= Publications in Language Sciences. 26).

Fanselow, Gisbert \& Felix, Sascha W.: Sprachtheorie. Eine Einführung in die Generative Grammatik. Bd 2: Die Rektions- und Bindungstheorie. - Tübingen: Francke 1987. 280 S. (= Uni-Taschenbücher. 1442).

Kemenade, Ans van: Syntactic case and morphological case in the history of English. Dordrecht \& Providence, RI: Foris Publications 1987. xi, 249 S.

Moosmüller, Sylvia: Soziophonologische Variation im gegenwärtigen Deutsch. Eine empirische Untersuchung. - Stuttgart: Franz Steiner Verlag Wiesbaden 1987. XIII, 222 S. (= Zeitschrift für Dialektologie und Linguistik. Beihefte. 56).

Sound patterns in second language acquisition. 〈Eds. >: Allan James and Jonathan Leather. - Dordrecht \& Providence, RI: Foris Publications 1987. 249 S. (= Studies on Language Acquisition. 5).

Spreda, Klaus W.: Tonologie des Metta 〈Western Grassfields〉: Eine autosegmentale Beschreibung des einfachen unabhängigen Satzes. Diss. Köln 1986. - Köln 1986: Selbstverlag. $242 \mathrm{~S}$.

Technisierte Kommunikation. 〈Hrsg.> Rüdiger Weingarten/Reinhard Fiehler. (Opladen): Westdeutscher Verlag (1988). 251 S. (Psycholinguistische Studien).

Uszkoreit, Hans: Word order and constituent structure in German. - Stanford: Center for the Study of Language and Information 1987. ix, 190 S. = CSLI Lecture Notes. 8.

Weingarten, Rüdiger: Verständigungsprobleme im Grundschulunterricht. - (Opladen): Westdeutscher Verlag (1988). 177 S. (Psycholinguistische Studien). 


\section{Zur Rezension angeboten}

The alphabet and the brain. The lateralization of writing. Ed. by D. de Kerckhove and C.J. Lumsden. - 1988. XVI, 455 S.

Angewandte Sprachwissenschaft. Interdisziplinäre Beiträge zur mündlichen Kommunikation. Hrsg. von Helma Behme. - 1988. X, 234 S.

Bamberg, Michael, G.W.: The acquisition of narratives. Learning to use language. - 1987. XIV, $245 \mathrm{~S}$.

Bernhard, Gerald: Die volkstümlichen Pflanzennamen im Val d'Aran〈Zentralpyrenäen 〉. 1988. XI, $175 \mathrm{~S}$.

Braun, Friederike: Terms of address. Problems of patterns and usage in various languages and cultures. - 1988. XIV, 374 S.

Bublitz, Wolfram: Supportive fellow-speakers and cooperative conversations. Discourse topics and topical actions, participant roles and ,recipient action 'in a particular type of everyday conversation. - 1988. xii, $308 \mathrm{~S}$.

Codeswitching. Anthropological and sociolinguistic perspectives. Ed. B. Monica Heller. 1988. vi, $278 \mathrm{~S}$.

Cooreman, Ann M.: Transitivity and discourse continuity in Chamorro narratives. - 1987. $\mathrm{x}, 246 \mathrm{~S}$.

Debus, Friedhelm/Eichler, Ernst/Walther, Hans: Benennung und Sprachkontakt bei Eigennamen. - 1988.

Driem, George van: A grammar of Limbu. - 1988. xxviii, $574 \mathrm{~S}$.

Erlinger, Hans Dieter: Studienbuch: Grammatikunterricht. - 1988. 156 S.

Fisiak, J.: A bibliography of writings for the history of the English language. Compiled and edited by J' $F^{\prime}$. 2. edition. 1987. xi, $216 \mathrm{~S}$.

Flaitz, Jeffra: The ideology of English. French perceptions of English as a world language. 1988. XIV, $226 \mathrm{~S}$.

The genesis of language. A different judgement of evidence. Ed. by Marge E. Landsberg. 1988. xiv, $278 \mathrm{~S}$.

Giesecke, Michael: Die Untersuchung institutioneller Kommunikation. Perspektiven einer systematischen Methodik und Methodologie. - 1988. VIII, 231 S.

Gislimberti, Silvio: Coesione testuale. Un'contrastiva 〈tedesco-italiano〉di commenti della stampa quotidiana. - 1988. VI, $236 \mathrm{~S}$.

Hockings, Paul: Counsel from the ancients. A study of Badaga proverbs, prayers, omens and curses. - 1988. xiv, $810 \mathrm{~S}$.

Jakobson, Waugh. Assisted by Martha Taylor: The sound shape of language. - 1987. xii, $555 \mathrm{~S}$.

Kohnen, Thomas: Zurückweisungen in Diskussionen. Die Konzeption einer Sprechhandlungstheorie als Basis einer empirisch orientierten Konversationsanalyse. - 1987. x, 291 S.

Künstliche Intelligenz. GWAI-88. 12. Jahrestagung, Eringerfeld, 19.-23. September 1986. Proceedings. Hrsg. von W. Hoeppner. - 1988.

Languages and cultures. Studies in honor of Edgar C. Polomé. - 1988 xvi, 792 S.

4. Österreichische Artificial-Intelligence-Tagung. Wiener Workshop Wissensbasierte Sprachverarbeitung. Wien, 29. - 31. August 1988. Proceedings. Hrsg. von H. Trost. 1988. VIII, $207 \mathrm{~S}$.

Patzelt, Werner J.: Grundlagen der Ethnomethodologie. Theorie, Empirie und politikwissenschaftlicher Nutzen einer Soziologie des Alltags. - 1987. $385 \mathrm{~S}$.

Pragmatics, discourse and text. Some systemically-inspired approaches. Ed. by Erich $\mathrm{H}$. Steiner, Robert Veltman. - 1988. 185 S.

Sridhar, S. N.: Cognition and sentence production. A cross-linguistic study. -1988 . x, $118 \mathrm{~S}$.

Vennemann, Theo: Preference laws for syllable structure and the explanation of sound change. With special reference to German, Germanic, Italian and Latin. - 1988. viii, 94 S.

The written world. Studies in literate thought and action. Ed. by R. Säljö. - 1988. IX, 214 S. 